\title{
El espíritu de las vanguardias: Vislumbres y perspectivas de un arte estrábico
}

\author{
The spirit of the avant-garde: \\ Insights and prospects for a crossed-eyed art
}

\author{
María Teresa Sánchez Carmona \\ Universidad de Sevilla \\ teresa_sc@hotmail.com
}

Recibido: 1 de febrero de 2012

Aprobado: 4 de abril de 2012

\begin{abstract}
Resumen
Muchos son los estudios que hasta la fecha se han realizado sobre los movimientos de vanguardias surgidos en Europa e Hispanoamérica desde comienzos del siglo XX. Este trabajo constituye una sucinta revisión en torno a las principales tendencias y perspectivas que asumieron algunos grupos y artistas de la época. Incluye asimismo la opinión que estas manifestaciones suscitaron en la crítica y el público general, instados por una nueva perspectiva artística y literaria que invita a contemplar la realidad desde una mirada caleidoscópica y prismática, susceptible de ser reinterpretada desde muy distintos puntos de vista. Miradas encontradas y esquivas, inocentes e incendiarias, cuya perspectiva no puede eludirse para comprender las manifestaciones artísticas y literarias vigentes en la actualidad. Miradas vueltas hacia la tradición pero recién nacidas, que comprenden la originalidad, el artificio y la verdad más profunda del arte en la época de las vanguardias.
\end{abstract}

Palabras clave: Vanguardias; Arte nuevo; Poesía experimental; Interdisciplinariedad.

Sánchez Carmona, M.T. (2013): El espíritu de las vanguardias:Vislumbres y perspectvas de un arte estrábico Arte, Individuo y Sociedad, 25 (1) 135-151

\begin{abstract}
Numerous critical studies to date have been conducted on the avant-garde movements that emerged in Europe and Latin America since the early twentieth century. This paper is a brief review about the main trends and prospects assumed by certain groups and artists of the time. It also includes the opinion these statements aroused among critics and the general public, prompted by a new artistic and literary perspective which invited to contemplate the reality from a kaleidoscopic prism, able of being reinterpreted from very different points of view. Eyes turned towards tradition but newly reborn, looking for the originality, the artifice and the deeper truth of art in the context of the vanguards of new century. Encountered and elusive, innocent and incendiary, these multiple perspectives allow us to understand and to admire the current artistic and literary works.
\end{abstract}

Key Words: Avant-Gardes; New Art; Experimental Poetry; Interdisciplinarity.

Sánchez Carmona, M.T. (2013): The spirit of the avant-garde:Insights and prospects for a crossed-eye art. Arte, Individuo y Sociedad, 25 (1) 135-151

Sumario: 1. El problema de la ubicación: "Los cuatro puntos cardinales son tres: el Sur y el Norte", 2. Cosmopolitismo vs nacionalismo: ambigüedad de la visión, 3. Esbozos y pinceladas de un arte nuevo: de lo espiritual en el arte, 4. Mascarada y provocación: en torno a la nueva identidad del artista, 5. Arte Diem: lo efímero, lo dinámico y lo experimental, 6. Entre lo sugestivo y lo manifiesto: guiños de refracción, 7. ¿Arte poli-género o síndrome de Diógenes? Pasando revista a publicaciones y manifiestos, Referencias. 


\section{El problema de la ubicación: "los cuatro puntos cardinales son tres: el Sur y el Norte" (Huidobro, 2001:57)}

Las primeras décadas del siglo XX constituyen una época convulsa cuyas especiales coordenadas sociales, políticas y económicas posibilitaron el surgimiento de nuevas tendencias artísticas acordes con las circunstancias imperantes. Éstas modificaron ese vasto horizonte abierto ante los artistas del Modernismo, cuyo espíritu se desplazaba "por encima de estanques, de valles / de montañas y bosques, de mares y de nubes, / más allá de los soles, más allá de los éteres, / más allá del confín de estrelladas esferas" (Baudelaire, 1998:14). La suya era la comprensión del poeta cercano a la iluminación pseudo-platónica que, desde la atalaya de sus versos, cantaba esas verdades inaccesibles como un sol en las alturas. Arte erigido como encumbrada torre de marfil (Rimbaud, 1994:123) firme y estática, fuerte y noble, casa-palacio de preciosismo y excelencia reservada a una minoría burguesa: "¡Torres de Dios! ¡Poetas!” (Darío, 1961:721). Se trataba de esa soberbia torre erigida por hombres que aspiraban a ser dioses, por los poetas demiurgos que se pavoneaban prestando su voz a los cisnes agonizantes.

Si la del cisne es una voz tan extremadamente bella como frágil, la torre modernista poseía una elegancia asimismo efímera y quebradiza. El comienzo del siglo XX, y de manera especial el periodo de entreguerras, abrió profundas brechas en el cuerpo y el alma de la población mundial, sembrando la ruina y la catástrofe, provocando la explosión y la crisis de todas las certezas que hasta aquel momento se habían considerado irrebatibles: "heme aquí en una torre de frío" confiesa Vicente Huidobro (2001:85). En ese invierno del alma los poetas contemplaron cómo su mundo se derrumbaba, diseminando por el suelo aquellos secretos hasta entonces reservados a unos pocos iniciados: rotos los exóticos jarrones y las estéticas figurillas de ensueño; los cristales y los espejos quebrados en mil pedazos (acaso la concreción más evidente de dicha metáfora se halla en la rotura del Gran vidrio de Duchamp). El cristal se vuelve vidrio fragmentario y caleidoscópico, mirada cubista que acoge perspectivas diversas y complementarias, palabra expresada en babélicas jergas dispersadas hacia los cuatro puntos cardinales.

En Hispanoamérica el cambio cultural se produjo bajo unas coordenadas similares, acentuado por esa magia intrínseca del terreno, ese realismo mágico susceptible de disolver y reformular toda percepción espacial: "los puntos cardinales se han perdido en el montón, como los ases de un juego de cartas" (Huidobro apud Osorio, 1988:201). Esta perspectiva utópica, esa excentricidad o ausencia de un punto fijo en el que confluyan las líneas espaciales, influyó notablemente en los artistas y su manera de situarse "en" y "respecto" a los acontecimientos. Cuando el poeta se hallaba en lo más alto de la torre, ésta se erigía como un axis mundi desde el cual verter una mirada profética, pero cuando la torre quedó derruida y los poetas bajaron del Olimpo (Parra, 1973:163-167) se vieron obligados a contemplar la realidad circundante y recrearla con una nueva mirada. Como el pájaro del Manifiesto Ultraísta, liberado de "esa vasta jaula absurda donde los rituales quieren aprisionarlo" (Videla, 1990:16), comenzaron a ensayar nuevos movimientos para comprobar que su libertad se extendía más allá de todo horizonte. Iniciaron una exploración del terreno buscando su propia identidad, para luego trascender su marco histórico (Osorio, 1988:IX). Iniciar un acercamiento 
a estas claves artísticas requiere entonces la consideración previa de las coordenadas en que las vanguardias fueron concebidas.

Desde finales del siglo XIX, y especialmente a comienzos del XX, se lleva a cabo un activo proceso de modernización: soplan nuevos vientos impulsores de la Segunda Revolución Industrial. Ya en la primera década del novecientos se fue configurando la cultura de masas, el populismo indiscriminado, el crecimiento demográfico, el aumento del poder adquisitivo y, en consecuencia, del consumo: la misma población consume los mismos productos elaborados mecánicamente en un mismo proceso en cadena. Mimetismo, copia, alienación. La máquina se convierte en el elemento estrella, trasunto de una sociedad cada vez más individualista y enajenada. El ser humano se concibe como un elemento más del engranaje social: corren tiempos modernos, de los que se hicieron eco películas como la de Charles Chaplin (1936), o Metrópolis (1927) de Fritz Lang.

El sistema capitalista se desarrolla en una sociedad "ávida Dollars" donde la fiebre del oro colonial aparece reformulada desde nuevos parámetros. En Hispanoamérica se asiste al progresivo desplazamiento del eje de inserción hacia el sistema económico mundial. Si el momento álgido deviene con la gran depresión de 1929, la progresiva consolidación de los regímenes autoritarios a partir de 1930 fue el sesgo que cambió radicalmente el panorama de los hasta entonces "felices años veinte" (en Perú el coronel Sánchez Cerro derroca al gobierno de Leguía; en Argentina el general Uriburu depone al gobierno democrático de Yrigoyen; en Brasil Getulio Vargas lidera la Revolución del 30; en Chile Carlos Ibáñez renuncia al gobierno y en 1932 se instaura la República socialista). La inestabilidad que trajeron consigo dichas polaridades contribuyó a incrementar la sensación de crisis generalizada, de la que se habían hecho eco numerosas obras literarias al otro lado del océano: Germinal (1889) de Émile Zola, ¡Krack! de Ventura Fraga (1903) o Las uvas de la ira (1939) de John Steinbeck.

Conforman un marco generalizado la belle époque criolla, las huelgas, las luchas obreras y una combativa federación de estudiantes. Esta época de cesantía e inflación tuvo consecuencias tan nefastas para la población como el cierre de los mercados exportadores de materias primas, o la necesaria emigración hacia las grandes ciudades. Éstas se habían convirtieron en el foco de todas las miradas gracias a los imponentes edificios estilo art decó, que llegó a Latinoamérica décadas más tarde que en Europa. Pero tras sus imponentes fachadas, la ciudad empezó a mostrar una cara hostil: la del monstruo antropófago que amenazaba con engullir a quienes pugnaban por sobrevivir en su terreno. El paso del entorno rural a la ciudad confiere a esta última unas características negativas hasta entonces atribuidas a la naturaleza, entendida como mater terribilis; este malditismo telúrico se reformula en el espacio urbano en obras como Lima la Horrible (1977) de Salazar Bondy.

En cuanto a la cultura y la educación, el analfabetismo afectaba prácticamente a la mitad de la población en torno a 1920. Algunos gobiernos promovieron intensas campañas para reconducir a los estudiantes hacia actividades productivas, favoreciendo el desarrollo de sectores como el comercio o la industria. Dichas reformas pretendían acallar estallidos sociales revolucionarios, como el ocurrido en México (1910), y suscitar la idea de un espíritu nacional y patrio que evitase 
disidencias y conflictos internos. La Universidad tuvo un papel preponderante en este sentido, proponiendo pautas reformistas como las que José Carlos Mariátegui planteó en Córdoba (Argentina).

Este ambiente cultural facilitó la recepción y asimilación de los ismos europeos, convirtiendo a ciertos países en receptores de numerosas obras extranjeras. Se lee a Camus, Kafka, Dostoievsky, Freud, Jung, H. Hesse, García Lorca, B. Shaw, H.G. Wells, Breton... Aunque estas corrientes de pensamiento venidas de Europa ejercieron una notable influencia, el arte hispanoamericano gozó de gran autonomía y manifestó un interés especial por dialogar con la propia realidad circundante para alzar una voz propia. Convivieron dos tendencias opuestas o, cuanto menos, complementarias: un arte de ecos europeístas, y otro centrado en lo folclórico y autóctono de la propia cultura.

\section{Cosmopolitismo vs nacionalismo: ambigüedad de la visión}

El factor espacio-temporal cumple un papel decisivo a la hora de sopesar la posición y predisposición artística de un grupo o un país, pues ayuda a considerar desde qué parámetros habla el artista, cuál es su centro y su periferia y, en caso de haberla, hasta qué punto puede ésta considerarse una excentricidad voluntaria o impuesta. Se requiere una mirada histórica que establezca relaciones de anterioridad con el pasado, de simultaneidad con el presente, y de proyección futura. Paul Ricoeur (1979) alude a esta proyección como un enrejado interpretativo, que confiere una dimensión social y colectiva a la experiencia del tiempo. Dado que toda contemplación resulta ensimismada y subjetiva, se requiere también la presencia de un referente externo u Otro lacaniano que considere la propia perspectiva desde parámetros más amplios (Lacan, 1975:59). Este libera la mirada de su parcialidad y se yergue como espejo o espada de doble filo que cuestiona la propia identidad, la posible mascarada, el pudoroso ocultamiento, el descarado travestismo.

Dos eran las miradas posibles: una centrada en la propia realidad, otra evasiva en busca de nuevos horizontes. Para quienes propugnaban una mirada nueva, los criollistas o nacionalistas no pasaban de ser un grupo de "artistas miopes" incapaces de focalizar su visión más allá de sus límites geográficos. En el caso contrario, los panegiristas del arte nuevo presentarían un claro caso de presbicia o "vista cansada" del panorama nacional, que les llevó a fijar su atención en los fuegos de luz y artificio, lanzados desde la moderna Torre parisina. La problemática entre dichas posturas antagónicas hunde sus raíces en una vieja confrontación, pues según Arturo Torres Rioseco ya durante el Modernismo aparecen dos tendencias contrapuestas: un primer momento de evasión, caracterizado por un imaginario de temas exóticos recurrentes, y una fase "mundonovista" que apostó por una vuelta a la tierra, la historia y el paisaje autóctono. Estos modos de contemplar la realidad fueron el germen de este estrabismo geográfico a comienzos del siglo XX.

En la literatura, la doble vertiente presenta estilos asimismo enfrentados. Tanto el criollismo como la poesía tradicional de corte romántico tendían a reproducir una mirada de tipo sentimental y descriptiva que rayaba la rusticidad de estilo. Como reacción a los valores europeístas propugnaban un arte que fuese expresión de la "raza 
étnica" y que universalizase sus raíces criollas. Este nacionalismo se hizo extensivo al contexto social, educacional, económico y político de la época. Frente a esa postura institucionalizada y vinculada a la tradición, las manifestaciones de vanguardia nacieron con actitud contestataria y rupturista, propugnando un nuevo sentido formal y funcional para sus obras. Se pretende un cuestionamiento que supere los antiguos parámetros de arte y pensamiento, vigentes a comienzos del siglo XX pero obsoletos para la sensibilidad de las nuevas generaciones. En Hispanoamérica los representantes de este nuevo sentir osado, iconoclasta e irreverente pretendían acabar con el provincianismo artístico, confiriendo a las vanguardias una vertiente cosmopolita. Muchos optaron por realizar viajes a otros países, retomando la imagen del "poeta globe-trotter sin oficio activo; globe-trotter poeta sin oficio pasivo" (Huidobro apud Osorio, 1988:200): los exploradores se vuelven poetas que cantan de pie sobre las olas derramadas, y los poetas se convierten en exploradores que buscan cristales en las gargantas de los ruiseñores.

En Hispanoamérica, la opción a favor del nuevo espíritu no fue una mímesis de los postulados europeos; como indica Osorio ésta no solo no es plagiaria de las vanguardias del otro lado sino que además ha hecho su aporte considerable y noble y alto y pesado (1988:XXVIII). A través del análisis de artículos y manifiestos se constata la explícita intención de los artistas latinoamericanos por distinguirse de los ismos europeos, utilizando la expresión de "arte nuevo" para evitar deliberadamente el término de "vanguardia" empleado en la otra orilla. En su artículo "Espíritu viejo y espíritu nuevo" (1924) el poeta Juan Emar recoge una anécdota clarificadora:

Un buen amigo de regreso de Nueva York -la gran ciudad moderna de los avisos de luz-me dijo desencantado ante Santiago: "En Nueva York, la ciudad modelo, todos los avisos están escritos en inglés. ¿Por qué aqui, ya que hay la buena intención de seguir los buenos modelos, se escriben los avisos en español?" [...] Habría sido tarea demasiado ardua convencerle de que en cada parte los letreros están en el idioma que el pueblo entiende, en la forma que corresponde y que obedece a una razón de ser viva...

El arte es siempre reflejo de un tiempo, un lugar y un sentir, aunque luego se trascienda a sí mismo para buscar nuevos horizontes expresivos: "en cualquier buena obra hay algo de universal pero humanizado por la tierra" (Emar apud Osorio 1988:143). De hecho, el crítico Naín Nómez considera que las posturas centralistas o periféricas, canónicas o marginales que se atribuyen a determinados grupos tienen más que ver con el particular enfoque metropolitano adoptado por los críticos que con la lejanía estética de los propios artistas. Según Jorge Schwartz las vanguardias latinoamericanas tuvieron mucho de imitación pero también mucho de originalidad; podría decirse que "buscaron inspiración en los ismos parisienses tanto como en los mitos indígenas y en los ritos afroantillanos" (1991:14). Algunos movimientos plantearon unas bases ideológicas firmes y una evolución duradera; otros manifestaron un carácter puramente lúdico y provocador para disolverse poco tiempo después. En ocasiones, los artistas oscilaron entre unas corrientes y otras a lo largo de su vida, buscando "una expresión al mismo tiempo universal y personal que habría de guiar 
sus poéticas y sus conquistas estéticas" (Bosi apud Schwartz, 1991:15), y aportando al conjunto de su obra gran variedad y riqueza.

Resulta, pues, indispensable entrar en ese juego especular y de especulación que E.H. Gombrich denominó "la ambigüedad de la visión" (2000:395), cuyo ejemplo más clarificador lo encontramos en obras polivalentes como Rostro de Mae West que puede usarse como apartamento surrealista (1934-35) y la Aparición de un rostro y un frutero en una playa (1938), ambas de Salvador Dalí (Descharnes \& Neret, 1994). Dado que esta búsqueda de identidad no presenta una única cara, conviene aceptar estas distintas mociones artísticas desde una integración por yuxtaposición (Ramírez, 2006:12), sistematizándolas como polaridades propias de una "generación bisagra" vanguardista que se antoja bilocada, bipolar, bifurcada y bígama entre dos continentes:

Hay en el hombre una dualidad que se manifiesta en todos sus actos, dos corrientes paralelas en las que se engendran todos los fenómenos de la vida. Todo ser humano es un hermafrodita frustrado (Huidobro, 1976:672-673).

\section{Esbozos y pinceladas de un arte nuevo: de lo espiritual en el arte (Kandinsky, 1996)}

Las primeras décadas del siglo XX desataron una crisis de valores en el seno de una sociedad, progresivamente transformada por la cultura de masas. Alienación de los individuos, mecanización de sus conductas, repetición de patrones de vida y estandarización de los objetos, valoración del ser por su rentabilidad productiva. Resulta interesante contrastar esta situación con la imagen de sociedad propuesta en tres de las novelas cumbre de la anti-utopía en el siglo XX: Un mundo feliz (Brave New World) de Aldous Huxley (1932); 1984 de George Orwell (1948) y Fahrenheit 451 de Ray Bradbury (1953). Estos factores unidos a las corrientes existencialistas, el derrumbe de antiguas filosofías, la consideración de un arte deshumanizado y el incalculable daño que provocaron las guerras mundiales, tampoco ayudaron a rescatar unos valores que iluminasen esa suerte de noche oscura: "Dios ha muerto" dice Nietzsche y, como en el pasaje bíblico de la Crucifixión, la tierra se estremece y el cielo tiembla (Huidobro, 2001)

Estas circunstancias incidieron en las manifestaciones artísticas de la época que, como vía de reflexión y expresión, quedaron impregnadas de esos sentimientos contradictorios, haciéndose eco de ellos a través de los temas y la estética adoptada. Por una parte el arte incorpora los elementos y materiales propios de la era del progreso, explorando nuevos y dinámicos métodos creativos para revolucionar el panorama artístico. Por otro lado, surgen tendencias rupturistas como respuesta a la crisis existencial que convulsionaba el mundo. De hecho en esta actitud transgresora se encuentra la verdadera raíz de la que habrían de germinar estos movimientos, pues "la vanguardia no está interesada en la novedad como tal, [más bien] intenta descubrir o inventar nuevas formas, aspectos, posibilidades de crisis [y] si la crisis no existe, hay que crearla" (Calinescu, 1991:126). Este arte del desencanto no resulta novedoso: Paz Castillo compara el sentimiento nuevo de vanguardias con el mal de siglo que afectó a la generación de finales del s. XVIII y principios del XIX, ya que ambos son expre- 
sión del "deseo de vida de una generación, el ansia de encontrar una expresión, una palabra acaso, que contenga algo de ese íntimo anhelo del alma humana a superarse siempre" (apud Osorio, 1988:309). ¿Afán de superación, búsqueda de evasiones o necesidad desesperada de llenar con palabras ese vacío abismal?

La poesía, y sobre todo en nuestro tiempo, es cosa de desesperados. Se escribe para olvidar superiormente que se va a morir, se escribe para olvidar superiormente que se vive, se escribe para olvidar la vida que se vive y para comunicar el olvido. Creo que la sombra de ese olvido y la comunicación de la sombra de ese olvido, sólo se obtiene por un ensimismamiento tal en el comercio con las palabras que no quede tiempo ni sitio para pensar en otra cosa (Paseyro, 2009:56).

Estas tendencias se erigen como un revulsivo que cuestiona e interroga la realidad circundante; no en vano, Guillermo de Torre definió las vanguardias como unas manifestaciones que sacudieron los nervios de toda Europa (2001). La propia terminología alude a su naturaleza combativa (del francés avant-garde, en alusión a los soldados situados en «primera línea» de avanzada). Cada movimiento en Hispanoamérica planteó sus postulados con un acento propio, renegando de la denominación "vanguardista" acuñada por los artistas europeos. De esta forma la mística del lenguaje abre puertas hacia una relectura sagrada del arte, ya que hablar de espíritu evoca la presencia de un aliento creador que se cuela por las hendiduras de las obras insuflándoles nueva vida. Se persigue una simbiosis o fusión tal que pudiera hablarse de vida y arte como de una sola realidad; el espíritu se encarna en las obras y, como tal, se mueve y respira y tiembla y actúa y juega y provoca y late y se transforma. Porque el arte como la vida es dinámico y efímero, y lo efímero muta pero no muere.

El arte nuevo adquiere su autonomía desde todos los puntos de vista: libertad de acción, de manifestación, de contemplación, de expresión, de experimentación, de pensamiento; libertad visual, mental, sensorial, interpretativa, interdisciplinar, polimórfica. Libertad total para creer y crear.

El arte nuevo exige interpretación, no definición. Toda definición tiene por base el concepto. Hoy queremos curarnos, tanto como nos sea posible, y sobre todo en estética, de la tiranía de la razón. Hemos padecido larguísima enfermedad de sensatez [...] ¿Se puede definir "eso" que llamamos poesía? Debemos convenir que no. La poesía es siempre anterior y ulterior a toda definición (Videla, 1990:130).

Se promueve el esfuerzo por conquistar esa libertad a partir de perspectivas que contemplen el mundo como por vez primera, contraponiéndose a la mirada vetusta y gris de un modernismo crepuscular. Se distingue un espíritu nuevo (el arte vivo de los jóvenes) frente al viejo espíritu ya oficializado. Lo interesante de este asunto es, dice Juan Emar, "que entre los jóvenes se encuentran a menudo artistas de sesenta y más años y que entre los viejos abundan adolescentes. Paradoja o ironía, no lo sé [...] pero no se trata de canas, se trata de espíritu" (1924). Esta misma opinión la defiende César Vallejo en su artículo "Poesía nueva", donde plantea que lo novedoso no reside tanto en la inclusión de nuevos términos cuanto en una cuestión de sensibilidad: 
Poesía Nueva ha dado en llamarse a los versos cuyo léxico está formado de las palabras "cinema, motor, caballos de fuerza, avión, radio, jazz-band, telegrafía sin hilos" [...] pero no hay que olvidar que los materiales artísticos que ofrece la vida moderna han de ser asimilados por el espiritu y convertidos en sensibilidad [...] En la poesía verdaderamente nueva pueden faltar imágenes o "rapports" nuevos, pero el creador goza o padece alli una vida en la que las nuevas relaciones y ritmos de las cosas se han hecho sangre, célula, algo en fin, que ha sido incorporado vitalmente en la sensibilidad (apud Osorio, 1988: 189)

Estos amplios márgenes en cuanto a la consideración de la edad del artista y la cronología de su quehacer plantean, a su vez, el problema de la datación de estos movimientos. Los críticos identifican la época de vanguardias con la década de los años 20 y parte de los 30 , manifestando su mayor esplendor durante el periodo de entreguerras. Hugo Verani (1986:11) considera 1916 y 1935 las fechas límite de dicho periodo histórico, Federico Schopf (1986:33-38) lo amplía hasta 1939, Nelson Osorio (1981:238) lo sitúa entre finales de la Primera Guerra Mundial y la crisis mundial del 29, Schwartz propone la fecha de 1914 (en que Huidobro procede a la lectura de su manifiesto Non serviam) como el momento inaugural de las vanguardias en Hispanoamérica. Otra posible opción es considerar la propuesta que hace Borges en su introducción al Índice de la nueva poesía americana (1926) tomando como referente el año 1922, fecha en que "surge una articulación única de circunstancias históricas y personales: el año del Ulises [de Joyce], The Waste Land [de T.S. Eliot], Trilce [de César Vallejo], Desolación [de Gabriela Mistral], la Semana de Arte Moderno en Sao Paulo, el nacimiento de Proa en Buenos Aires y del estridentismo con Actual, hoja de vanguardia" (Borges, 1979:327). Fue éste también el año de 'publicación de Veinte poemas para ser leídos en el tranvía de Oliverio Girondo, de Andamios interiores de Manuel Maples Arce y de la Generación poética de 1922 en Buenos Aires. Baste apuntar, en definitiva, que los años 20 fueron el momento de eclosión y máximo desarrollo de estos movimientos, cuya extinción suele situarse hacia finales de dicha década, tomando como referentes la muerte del surrealismo en Europa (que Vallejo enterró con su artículo "Autopsia del Surrealismo" en 1930) y en Hispanoamérica la del Movimiento de Vanguardia en Nicaragua (1931).

Y sin embargo, ¿puede considerarse enterrado un espíritu que ha seguido alentando nuevas obras en el arte actual, sólo porque haya modificado determinadas prácticas o porque las circunstancias históricas sean otras? Si bien lo que se conoce como vanguardia queda vinculado al periodo de entreguerras, no pueden obviarse las manifestaciones de "posvanguardia" y "neovanguardia", cuyo espíritu de experimentación, cuestionamiento, revulsión social y constante creación participa de ese mismo espíritu latente en el siglo pasado, que ha pervivido y se ha renovado más allá de terminologías y grupos concretos. 


\section{Mascarada y provocación: en torno a la nueva identidad del artista}

Este nuevo espíritu de vanguardias se erige como un arte total, según lo refiere el Primer Manifiesto Dadá (1918): una ideología total, una forma de vivir que connota el rechazo a toda tradición o esquema de pensamiento anterior. Dicho arte trasgrede los límites interdisciplinarios, disuelve las fronteras con la vida, aúna al creador y al espectador en un mismo espíritu, y cuestiona y replantea tanto el papel del artista como el diálogo que éste mantiene con la sociedad. Considerando que la crisis de identidad afectaba al ser humano en todas sus facetas, no resulta fácil dar una versión unívoca sobre la naturaleza y la praxis del artista de vanguardias. Se habla tan sólo de un arte libre en oposición a otros enfoques del pasado, tal como la condición de artesano concebida en la época medieval o aquélla que, en siglos posteriores, le sujetaba a un mecenazgo político e ideológico. Se recupera el modelo de arte humanista que comprende múltiples saberes desde una clave multidisciplinar; pero se da un paso más al liberar al artista de la obligación de manifestar su virtuosismo metodológico: la belleza perseguida es ahora otra, basada no en una particular estética sino en el deseo de transformar la vida en arte y el arte en verdadera obra viva.

La poesía se concibe como praxis vital y palabra en movimiento que se expresa a través de rostros y gestos concretos. Superado el noli me tangere que salmodiaban los encumbrados poetas modernistas, el arte se populariza e invade las calles para transformarlas en una suerte de Teatro Mágico (Hesse 1973:178-ss) lleno de soñadores (Breton), humoristas "greguerianos" (Gómez de la Serna), pilotos de carreras (Marinetti), magos (Huidobro), narcisistas (Dalí), locos cuerdos (Artaud), ajedrecistas (Duchamp), saltimbanquis (Picasso) y patafísicos (Alfred Jarry).

"En este mundo invertido la única atracción posible es la que ejercen los disfraces" (Sarduy, 1969:46). Pero ¿existe esa fusión total entre artista y obra, así como una total libertad de expresión sin ataduras ideológicas? ¿Cuál sería el tipo de diálogo que el artista establece con la sociedad y la política de su tiempo? La relación de dependencia-independencia-interdependencia del arte ha sido un tema largamente debatido. Conocida es ya la postura de Ángel Rama en su obra La ciudad letrada, donde refiere que la intensa vida de creación literaria que desarrollaron los poetas y "esa concentración en el orbe privativo de su trabajo - la lengua y la literatura - no los retrajo de la vida política" (1984:107-108), antes bien "en el 900 estaba viva la vocación política de los escritores, y aún desmesurada por un modelo que, pareciendo francés, potenciaba la larga tradición redentorista del letrado americano" (116). Julio Ramos considera que el papel del artista y su compromiso o autonomía son directamente proporcionales al grado de modernización social del país, ya que éstos "no pueden reducirse de ningún modo a la ideología del arte por el arte" (2003:264). Jorge Schwartz expone que dicha "autonomización" del arte se produjo en consonancia con la especialización técnica y humana de la nueva sociedad industrial. Autonomía y libertad fueron los postulados que todos los artistas de vanguardias propugnaron abiertamente: "dar forma libremente, pensar libremente, expresar libremente. Éste es el legado verdaderamente radical del espíritu nuevo que las vanguardias latinoamericanas transmitieron a sus respectivos contextos nacionales" (apud Schwartz, 1991:19). 
Esa libertad se traduce en un cambio de la relación arte-sociedad y literaturapoder. El máximo objetivo era cortar las ataduras del arte con el sistema burgués en que se había situado durante los dos siglos anteriores (Bürger, 1987). Algunos lo consiguieron, otros no tanto. En algunos casos se mantienen esos valores burgueses, no ya por vasallaje sino por convencimiento. En contraposición a esta postura, otros artistas comenzaron una revolución comunista, asumiendo una actitud de compromiso social y político. En todo caso ciertas manifestaciones literarias y artísticas de vanguardias manifestaron un cierto elitismo en cuanto al público de sus obras. Dicho elitismo no estaba basado en la clase social, sino en la capacidad intelectual de un espectador al que se pone constantemente a prueba. Ello suscitó su impopularidad, en su doble acepción:

El arte nuevo, por lo visto, no es para todo el mundo, sino que va dirigido a una minoría especialmente dotada. Cuando a uno no le gusta una obra de arte pero la ha comprendido, se siente superior a ella y no ha lugar a la irritación. Mas cuando el disgusto que la obra causa nace porque no se ha entendido, queda el hombre como humillado, con una oscura conciencia de su inferioridad que necesita compensar mediante la indignada afirmación de sí mismo frente a la obra (Ortega, 2009:14).

Se establece una dialéctica basada en un pacto de conocimiento entre el espectador y el artista, que ningunea las estructuras de su tiempo a través de la provocación y la ironía (Ortega, 2009:49). Algunos recuperan la máxima "épater le bourgeois" proclamada por los poetas franceses finiseculares, con un enfoque eminentemente lúdico: el arte se convierte en juego, farsa y burla que expande los límites de lo posible y salva al hombre de la seriedad de la vida (48). Con Dadá a la cabeza: "no he oído ni leído, en relación con el movimiento Dadá, sino condenaciones o risas. Reír ya es algo. Es aun mucho, sobre todo en nuestra época sombría. Dadá lo consigue sin gran trabajo" (Osorio, 1988:76). Se trata de la legitimidad de un humor irónico e inteligente que, bajo su apariencia de violenta comicidad, esconde un profundo cuestionamiento social: "no hay nada más profundo que la superficialidad", confiesa Kandinsky (1996:94).

La ruptura del pacto de confianza, el juego de apariencias, el "improve yourself" del arte nuevo (sólo lo difícil resulta estimulante, dice José Lezama Lima) coloca al espectador en una situación inestable. Crisis por el desasosiego que suscita la incapacidad de entender la obra; crisis también por el vértigo de un arte de la oscilación (Vergara, 1994:66). Las nuevas generaciones se escudan en su aparente inexperiencia para defender el derecho al ensayo y la equivocación: "Fail, fail again, but fail better" postula Samuel Beckett. Es preciso considerar la teoría de Erich Fromm sobre el proceso de aprendizaje, al referir que éste - como el amor - requiere el dominio de una teoría y de la práctica (Fromm 2005:17). Por este motivo resultaba perfectamente plausible que el artista cambiase de opinión para ensayar nuevos puntos de vista a lo largo de su trayectoria. Un ejemplo literario evidente son los Ejercicios de estilo (1947; 2004) de Raymond Queneau. 
Se recupera el interrogante de si el arte total permite una total libertad ideológica al artista en relación a la política y la sociedad. Podría considerarse que el humor y la farsa le liberan para adoptar a voluntad unas u otras actitudes, en base al legítimo derecho al ensayo, las leyes de la mutabilidad, el azar objetivo, o el puro deleite de la provocación. ¿Inocencia o cinismo? Duchamp abandona temporalmente su proceso creativo para dedicarse a jugar al ajedrez. ¿Autonomía o indiferencia? El arte se vuelve lúdico y se permite jugar a dos bandas, introduciendo además la dimensión del sugerimiento (Huidobro, 1914), que obliga al lector a abandonar su rol pasivo de espectador-voyeur para cumplir una función activa e intelectiva. El público aparece exaltado al rango de colaborador (y cómplice) del poeta.

\section{Arte Diem: lo efímero, lo dinámico y lo experimental}

Uno de los rasgos más sobresalientes es la importancia concedida al dinamismo: el arte como realidad viva y en movimiento; el rol activo de los espectadores obligados a hacer equilibrismos intelectivos para alcanzar la comprensión de la obra. Los grupos y movimientos de vanguardias se suceden en el panorama artístico como repeticiones de ese temblor que sacude la sociedad de entreguerras: "eclosión cáustica y ebullidora" que se menciona en el Cartel Runrúnico No 1, de 1928 (Osorio, 1988:326); fluir nervioso y "trote llovido que atraviesa las venas" (Girondo, 2000:133); tiempo que pasa con la velocidad de un automóvil rugiente de inspiración marinettiana; electricidad estática de una rueda duchampiana de bicicleta, del agitar una bolsa para sacar al azar el puñado de palabras que conformen un poema (Tzara, 2008:50-51). Se evoca una pedagogía del movimiento "basada en una formulación transitoria del arte, que no obtiene valor sino por el intercambio que origina en la sociedad" (Pizarro, 1995:20). Dicha transitoriedad, formulada por Baudelaire a mediados del XIX, pasa a definirse como un valor absoluto contra la tradición y el pasado. Movimiento fugaz: las manifestaciones de vanguardias aparecen en el firmamento artístico como una lluvia de meteoros cuya velocidad, al contacto con esa determinada atmósfera, los vuelve incendiarios antes de estallar en mil pedazos. El origen lo encontramos en el coche de carreras del Manifiesto futurista (1909) de Filippo Tomasso Marinetti.

Esa velocidad del movimiento es trasunto del fluir amenazante del tiempo, ese tempus fugit virgiliano que reaparece para impulsar al hombre hacia el progreso, bajo la influencia de las teorías einsteinianas, la mecánica cuántica y la física de partículas. Los poetas asumieron el carpe diem, "conscientes de que tenemos la obligación de vivir y sentir el minuto que se va y de que carecemos del derecho de hurtarle sitio a las generaciones futuras con obras frías y fósiles, que por frías y fósiles permanecen" (Uslar Pietri Osorio, 1988:274). Para expresar el vértigo se recurre a imágenes de la modernidad como el coche de carreras, los aeroplanos o los tranvías; como dice Cocteau "todo es cuestión de velocidad, velocidad inmóvil. La velocidad en sí. Opio: la velocidad de seda" (2002:99).

El arte nuevo es efímero porque las obras que se fijan cristalizan su sentido y mueren. Esta consideración suscita una interactividad y una interdisciplinar como la esgrimida por los objetos de manipulación recomendable u obligatoria de Duchamp, los caligramas apollinerianos, los cadavre-exquis, el action painting de Pollock y 
los ballets instantaneístas de Erik Satie. Las obras se llenan de alusiones a imágenes en movimiento (la novela-film Cagliostro de Huidobro) y el cine se convierte en soporte vivo de obras artísticas (como plasmaría décadas más tarde la película de Akira Kurosawa, Los sueños, 1990). Esto permite entender el rechazo que los artistas de vanguardia manifestaron hacia los museos, convertidos en catafalcos y ataúdes que encerraban un arte moribundo y obsoleto. Ellos optaron por llevar el arte a la calle, alzando sus voces estridentes y revulsivas para proclamar la belleza de un arte fugaz. En la literatura, ese gusto por lo efímero se cultiva mediante el haiku y el koan. Matsuo Basho decía que el haiku es simplemente lo que está sucediendo en ese lugar y en ese momento, la intuición pura del aquí y ahora plasmada en pocos versos (1986). Esta tendencia tuvo un impacto especial en la literatura occidental ya desde los simbolistas franceses, inspirando versos a R. Aldington, F. S. Flint, Ezra Pound (1986), Margaret Randall, Jack Kerouac, A. Ginsberg, E. Ferlinghetti o los componentes de la Beat Generation americana.

En Hispanoamérica los puso de moda el mexicano José Juan Tablada con la publicación de Un día... Poemas sintéticos (1919) y El jarro de flores (1922), si bien su cultivo se extendió gracias a poetas como los mexicanos Gabriela Rábago Palafox, Elías Nandino, Francisco Monterde, Jaime Torres Bodet, Rafael Lozano u Octavio Paz (que tradujo el famoso libro de Matsuo Basho Oko no Hosomichi en colaboración con Eikichi Hayashiya, 1957). Borges desarrolló un notable interés por el budismo y la filosofía oriental, destacando su tratado Siete noches y su libro La cifra (1981). Cortázar, si bien no cultivó el haiku, posee un libro póstumo (Salvo el crepúsculo) cuyo título procede de un poema de Basho que reza: "Este camino / ya nadie lo recorre / salvo el crepúsculo". Destacan también Jorge Carrera Andrade en Ecuador, la cubana Ana Rosa Nuñez, Víctor Manuel Crespo en Venezuela, Víctor Sánchez Montenegro o José Umana Bernal en Colombia, los peruanos Alberto Guillén, José Watanabe Varas o Jorge Eduardo Eielson; el uruguayo Mario Benedetti y Flavio Herrera en Guatemala.

\section{Entre lo sugestivo y lo manifiesto: guiños de refracción}

El carácter polifacético, lúdico y permisivo de las vanguardias podría sugerir erróneamente que este arte se reduce a la mera provocación casi carnavalesca. Pero detrás de cada máscara se oculta un rostro de verdad que contempla en lo profundo, jugando con el valor de la sugestión: ese oscilar sutil entre lo manifiesto (o explícito) y lo latente (o posible), separados apenas por la frágil línea de lo infraleve. El arte de vanguardias hace equilibrios entre ambos planos del espejo - como la Alicia de Carroll - distorsionando su reflejo en la especulación: lo mutable se reivindica como verdad inamovible; la imaginación crea mundos oníricos en estado de vigilia, y se proclama de manera consciente el valor de la inconsciencia. Las vanguardias son ante todo un arte de pensar que promueve la reflexión sirviéndose, precisamente, de la aparente ausencia de razón durante el proceso creador. En dicha sutileza recae su mayor muestra de ingenio. Combaten la indiferencia pero además - señala Ortega lo sentimental queda erradicado en favor de lo mental, combatiendo el naturalismo, el realismo y el vacuo mimetismo esgrimido por generaciones anteriores. 
Apollinaire había propugnado ya la importancia de un discurso que estableciese una tensión constante entre lo manifiesto y lo latente. Abogaba por una escritura con elementos de la realidad extraídos no de la visión, sino del conocimiento intuitivo (1957:31). Surge una literatura filosófica acorde con los postulados de pensadores como Spinoza o Hegel, padre de la filosofía moderna cuyas teorías sentaron la base del marxismo, el preexistencialismo de Kierkegaard, la metafísica nietzscheana, el pensamiento de Sartre, las teorías de Bataille o el deconstructivismo de Derrida. También influyeron reflexiones como las planteadas por Ludwig Wittgenstein (en torno al lenguaje y el valor del silencio), Ortega y Gasset o Unamuno, que escribió interesantes reflexiones sobre el panorama cultura de Hispanoamérica (1957).

Conocimiento y poesía se aúnan en el panorama literario abriendo puertas hacia lo inefable, y despertando lo insólito a través de la conjugación del lenguaje racional y el simbolismo. "La poesía es la palabra exacta, la palabra en que se alberga la esencia de la cosa nombrada; cuando se encarna lo nombrado, la palabra se electriza, es poesía, conocimiento" (Paseyro, 2009:21). Coincide con la idea expuesta por José Ángel Valente en Las palabras de la tribu (2002), donde declara que la poesía es, antes que cualquier otra cosa, un medio de conocimiento de la realidad. Esta dimensión filosófica del arte nos introduce en el ámbito de la poesía conceptual, donde las ideas rebasan los lugares comunes de la sensibilidad para alcanzar el conocimiento de lo absoluto. Dicha conceptualización lleva a que el proceso artístico se enfoque como actividad mental que comprende funcionamiento real del pensamiento, defendido por Breton, y la actividad del espíritu de Tzara.

Si bien la reflexión parte del racionalismo da también cabida a lo irracional, lo onírico y el absurdo como caras de un único prisma. Se pretende que la reflexión filosófico-artística trascienda los límites del pensamiento para, con clara orientación kantiana, dar cabida a la experiencia empírica como método cognoscitivo. Ésta constituye la base de toda la experimentación vanguardista. Resulta particularmente ilustrativa la reflexión sobre la estética y su aplicación poética que Pablo de Rokha expone en Estimativa y método, donde hace hincapié en que el filósofo-artista conjugue y equilibre conocimiento y experiencia, conciencia y subconsciencia, reflexión e intuición, concepto e imagen, racionamiento y estilo, verdad lógica y verdad estética (Mendoça, 2009:100-103)

El artista debe aplicar una lógica y una sabiduría intuitiva que le permitan ver lo que se esconde más allá de lo aparente: el alquimista se vuelve científico, los experimentos para hallar la piedra filosofal se convierten en rigurosos y exhaustivos análisis del lenguaje poético y visual, a fin de encontrar la palabra e imagen exactas. En "La creación pura. Ensayo de Estética" (publicado por primera vez en L'Esprit Nouveau $\mathrm{n}^{\mathrm{o}} 7$, abril de 1921, París) Vicente Huidobro propugna "alejarnos lo más posible de la metafísica y aproximarnos cada vez más a la filosofía científica" (Osorio, 1988:92). Para otros escritores, como Nicanor Parra, la palabra exacta se traduce en un lenguaje prosaico y conversacional capaz de nombrar la realidad sin misticismos, recurriendo la mordacidad histriónica que derrumbe la visión canónica y consagrada.

A estos modos de aproximación a la realidad se suma eso que Gérard de Nerval consideraba el derramamiento del sueño en la realidad, esa dimensión de conocimiento que comprende lo irracional, expresado a través de la imaginación simbólica y los 
sueños. "La verdadera obra de arte nace misteriosamente del artista por vía mística" (Kandinsky, 1996:101). Vía que los miembros del grupo surrealista identificaron con l'amour fou, al que accedieron por la auto-enajenación, el extrañamiento del "yo", el automatismo psíquico puro, la asociación mental libre, la escritura automática, y métodos como el "paranoico-crítico" propugnado por Dalí.

En Hispanoamérica interesa la actividad pictórica desarrollada por Remedios Varo, Leonora Carrington, el cubano Wilfredo Lam o el chileno Roberto Matta. En literatura destacan los peruanos César Moro, Xavier Abril y Emilio Adolfo Westphalen (que influyó sobre Pablo Neruda, Gonzalo Rojas o César Vallejo), Julio Cortázar o Alejandra Pizarnik en Argentina, y Octavio Paz en México. En Chile el Surrealismo tuvo una relevancia especial con el Grupo Mandrágora (1938), fundado por Braulio Arenas, Teófilo Cid, Enrique Gómez Correa y Jorge Cáceres. En este país encontramos además una oleada de escritoras que, a comienzos del siglo XX, pusieron en boga una escritura denominada "espiritualismo de vanguardia", que desbordaba los límites de la religiosidad tradicional propugnando una apertura hacia filosofías de influencia hinduista, teosófica y espiritista. Sus principales representantes fueron Eloísa Díaz, Amanda Labarca, Winétt de Rokha, Olga Acevedo, María Monvel, Chela Reyes y Gabriela Mistral.

\section{7. ¿Arte poligénero o síndrome de Diógenes? Pasando revista a publicaciones y manifiestos}

Este arte total que busca impactar a la sociedad permite comprender el afán de exploración y experimentación a través del cultivo de todo tipo de disciplinas, fusionadas para alcanzar nuevos recursos expresivos. Se promulga la superación de viejas taxonomías, pues sólo desde la desfragmentación estructural será posible comprender el espíritu rupturista y libertario de esta época.

Pierre Reverdy dijo que un arte nuevo requiere una sintaxis nueva. A partir de esta consideración van apareciendo voces, poemas, objetos, obras, manifiestos, artefactos y carteles que configuran un abigarrado panorama, reflejo de un horror vacui existencial a la par que estético. Esta búsqueda inspira el deseo de aglutinar diversas formas de expresión artística con la ciencia y la tecnología: "la poesía es hoy el álgebra superior de las metáforas" (Ortega, 2009:36). Su huella se evidencia en los temas (protones, electricidad, velocidad centrípeta, el cálculo, la geometría), métodos y soportes utilizados. ¿Arte poligénero o complejo de Diógenes? Surge el interrogante de si cualquier objeto o disciplina es susceptible de considerarse artística, o si el afán de ruptura ha ido demasiado lejos, dando cabida a manifestaciones que no comparten dicha naturaleza.

El espectador se ve obligado a adoptar una mirada amplia y abarcadora, acorde con este arte aquejado de estrabismo. Si los poetas optan por la mascarada y el travestismo lingüístico-visual, el espectador (elevado a la categoría de voyeur) tendrá que recoger las máscaras y atuendos que éstos van dejando como prenda de su delirio. Los ismos buscaron la dimensión proyectiva e interactiva del arte, fomentando una experiencia sensorial de la que hablan poemarios como Ver y palpar (1923-1933) de Vicente Huidobro, u objetos como los "ready-mades de manipulación obligatoria" 
duchampianos. Su integración en la vida cotidiana comprendió estrambóticos actos y performances que adoptaron como modus vivendi. En el ámbito literario ese despliegue expresivo se llevó a cabo a través de revistas, collages, carteles y manifiestos donde palabra e imagen fueron enarboladas como punta de lanza.

En Hispanoamérica, como en Europa, se sucedieron las revistas fundadas por los nuevos grupos de vanguardia. Estas publicaciones de naturaleza efímera constituyeron un vehículo excepcional para testimoniar el surgimiento de nuevos grupos y difundir sus ideas. Si bien el soporte no era novedoso, sus contenidos y postulados impulsaron la renovación del contexto artístico y literario en cada país. En Hispanoamérica destacaron La Nación, Los pensadores, Claridad, Proa y Martín Fierro (Buenos Aires); Variedades, El Imparcial, Amauta y Labor (Lima); El Universal Ilustrado y El Maestro (México D.F.); Klaxon y Diário Nacional (São Paulo); la Revista de Avance (La Habana); La Pluma (Montevideo), y Claridad, Nguillatún, Caballo verde para la poesía, Total, Primero de Mayo, Revista Nueva o Aurora de Chile (Santiago de Chile).

Se emplearon soportes como Carteles y Hojas informativas que, colgados en las calles, constituyeron un ejemplo de poesía visual que jugaba con el blanco de la página y la disposición del texto. Se recupera el estilo caligramático de Apollinaire recurriendo a originales técnicas de impresión como reclamo pictórico. El texto poético se convierte en pintura que se despliega y contorsiona en el papel para evocar sensaciones y emociones: la letra convertida en pincelada impresionista, el mensaje en faro capaz de iluminar nuevos horizontes. En ocasiones incluyen dibujos y fotografías, innecesarias para un texto de por sí pictórico: "pintura convertida en texto que se convierte en pintura. Colores plegados, letras cromáticas y no discurso a secas" (Sarduy, 1969:23). Las fronteras artísticas se diluyen. Algunos ejemplos significativos son el Cartel Runrúnico en Chile, la Hoja de Vanguardia en México y la revista mural Prisma en Argentina.

En definitiva, todas estas manifestaciones pictóricas, literarias, artísticas y estilísticas plantearon una nueva política poética en el arte y el pensamiento de la modernidad. Su rebeldía crítica y el afán por superar todo límite cognoscitivo y artístico se fraguó a través de la interdisciplinariedad y la absoluta libertad artística. Su esencial estrabismo fomentó el surgimiento de una mirada más amplia, autónoma y abarcadora respecto de la sociedad de aquel tiempo. Se atrevieron a mirar de frente lo prohibido sesgando, como hiciera Buñuel en su película Un perro andaluz, aquellos planteamientos fijados desde una óptica parcial y exclusiva. Paradójicamente, el sacrílego acto de contradecir las tendencias y postulados de su tiempo, para iluminarlas con su mirada incendiaria, erigió al nuevo espíritu de vanguardias en un arte tan popular y espontáneo como profético y sagrado. Porque, en palabras de Bataille:

lo sagrado es esencialmente comunicación: es contagio. Lo sagrado se presenta cuando, en cierto momento, se desencadena algo que tendría que ser detenido y que no se puede detener, que se dirige a la destrucción y que corre el riesgo de trastornar el orden establecido. Lo sagrado, si se presta atención, podría sencillamente reducirse al desencadenamiento de la pasión (2008:25). 


\section{Referencias}

Apollinaire, Guillaume. (1957). Los pintores cubistas: Meditaciones estéticas, Buenos Aires: Nueva Visión.

Basho, Matsuo. (1986). Haiku de las cuatro estaciones, Madrid: Miraguano.

Bataille, Georges. (2008). La religión surrealista: Conferencias 1947-1948, Buenos Aires: Las Cuarenta.

Baudelaire, Charles. (1998). 42 flores del mal, Madrid: Grijalbo Mondadori.

Bernardet, Caroline. (2010). El autorretrato, la auto-representación, El Calamo Web (http://www.elcalamo.com/benardet1.html). Consultado enero 2010

Biblia de Estudio: Dios habla hoy. (2002). Madrid: Sociedad Bíblica de España Claret.

Borges, Jorge Luis. (1979). Nota sobre la otra vanguardia, Revista Iberoamericana 106-107 (enero-junio), p. 327.

Bürger, Peter. (1987). Teoría de la vanguardia, Barcelona: Península.

Calinescu, Matei. (1991). Cinco caras de la Modernidad, Madrid: Tecnos.

Cocteau, Jean. (2002). Opio - Diario de una desintoxicación, Valencia: MCA.

Darío, Rubén. (1961). Poesías completas, Madrid: Aguilar.

De Torre, Guillermo. (2001). Historia de las literaturas de vanguardia, Madrid: Visor Libros.

Descharnes, Robert. \& Neret, Gilles. (1994). Salvador Dalí 1904-1989, Köln: Benedikt Taschen.

Ekai, Mumon. (2008). La puerta sin puerta: Cuarenta y ocho koan, Palma de Mallorca: El Barquero.

Emar, Juan. (1924). Espíritu viejo y espíritu nuevo, La Nación (mayo), Santiago de Chile.

Fromm, Erich. (2005). El arte de amar, Barcelona: Paidós Ibérica.

Girondo, Oliverio. (2000). Veinte poemas para ser leidos en el tranvía: Calcomanías y otros poemas, Madrid: Visor de Poesía.

Gombrich, Ernst Hans Josef. (2000). Art and Illusion, Princeton/Oxford: Princeton University Press.

Hesse, Herman. (1973). El lobo estepario, Madrid: Alianza Editorial.

Huidobro, Vicente.(1914). El arte del sugerimiento, Pasando y pasando... Crónicas y comentarios, Santiago de Chile: Imprenta y Encuadernación Chile.

(1976). El Creacionismo, Obras Completas I (a) - II (b), Santiago de Chile: Andrés Bello.

(2001). Altazor. Temblor de cielo, Madrid: Cátedra.

Jimeno-Grendi, Orlando. (2005). Mandrágora mántica, Anales de Literatura Chilena 6, Año 6, diciembre 2005, pp. 109-118.

Kandinsky, Vasili. (1996). De lo espiritual en el arte, Barcelona: Paidós Ibérica.

Lacan, Jacques. (1975). La función y el campo del habla y la lengua en psicoanálisis, Escritos I, Buenos Aires: Siglo XXI.

Lizama, Patricio. \& Zaldívar, María Inés. (2009). Bibliografía y Antología crítica de las Vanguardias Literarias en Chile, Madrid: Vervuert. 
Mendoça Telles, Gilberto. \& Muller-Bergh, Klaus. (2009). Chile y países del Plata: Argentina, Uruguay, Paraguay, Vanguardia Latinoamericana. Historia, crítica y documentos V, Madrid: Iberoamericana.

Ortega y Gasset, José. (2009). La deshumanización del arte, Madrid: Alianza Editorial.

Osorio, Nelson. (1981). Para una caracterización histórica del vanguardismo literario hispanoamericano, Revista Iberoamericana 114-115 (enero-junio), p. 238. (1988). Manifiestos, proclamas y polémicas de la vanguardia literaria hispano americana, Caracas: Biblioteca Ayacucho.

Parra, Nicanor. (1973). Obra gruesa, Santiago de Chile: Editorial Universitaria. (2007). Discursos de sobremesa, Santiago de Chile: Universidad Diego Portales.

Paseyro, Ricardo. (2009). Poesía, poetas y antipoetas, Madrid: Siruela.

Pizarro, Ana. (1995). Modernidad, Posmodernidad y vanguardias. Situando a Huidobro, Santiago de Chile: Fundación Vicente Huidobro.

Pound, Ezra. (1986). El arte de la poesía, México D.F.: Joaquín Mortiz.

Queneau, Raymond. (2004). Ejercicios de estilo, Madrid: Cátedra.

Rama, Ángel. (1984). La ciudad letrada, Hanover (New Hampshire): Ediciones del Norte.

Ramírez, Juan Antonio. (2006). Duchamp. El amor y la muerte, incluso, Madrid: Siruela.

Ramos, Julio. (2003). Desencuentros de la modernidad en América Latina: literatura y politica en el siglo XIX, Santiago de Chile: Cuarto Propio.

Ricoeur, Paul. (1979). El tiempo y las filosofías, París: Unesco.

Rimbaud, Arthur. (1994). Poesía completa, Barcelona: Fontana.

Sarduy, Severo. (1969). Escrito sobre un cuerpo, Buenos Aires: Sudamericana.

Salazar Bondy, Sebastián. (1977). Lima, la horrible, México: Era.

Schopf, Federico. (1986). Del vanguardismo a la antipoesía, Roma: Bulzoni.

Schwartz, Jorge. (1991). Las vanguardias Latinoamericanas. Textos programáticos y críticos, Madrid: Cátedra.

Tzara, Tristán. (2008). Siete manifiestos Dadá, Barcelona: Tusquets.

Unamuno, Miguel de. (1957). Algunas consideraciones sobre la literatura hispano americana, Madrid: Espasa-Calpe.

Valente, José Ángel. (2002). Las palabras de la tribu, Barcelona: Tusquets.

Vázquez, Ángeles. (2005). Revista Prisma de Argentina, Centro Virtual Cervantes (http://cvc.cervantes.es) [publicado en abril 2005; consultado en octubre 2009].

Verani, Hugo. (1986). Las vanguardias literarias en Hispanoamérica, Roma: Bulzoni. Vergara, Sergio. (1994). Vanguardia literaria: ruptura y restauración en los años '30, Concepción-Chile: Ediciones Universidad de Concepción.

Videla Rivero, Gloria. (1990). Direcciones del vanguardismo hispanoamericano II - Documentos, Mendoza - Argentina: Universidad Nacional de Cuyo - Facultad de Filosofía y Letras. 